\title{
The Analyze of the Risk Management and Control of Internal Audit
}

\author{
Dr. Hava Mucollari ${ }^{1}$ \\ Dr. Zaim Korsi² \\ Dr. Evis Çelo 3 \\ Prof. Dr. Alba Dumi ${ }^{4}$ \\ 1.2 Department of Accounting, UET University" Albania, \\ ${ }^{3}$ Letters Department, University of Vlore, Albania \\ 4Dean of Graduated School, Management Department" Economy Faculty University of Vlore, Albania \\ Email: alba.besi12@gmail.com
}

Doi:10.5901/ajis.2015.v4n3s1p440

Abstract

The need to manage risk has arisen in many areas and approaches used at each field reflect the skills and interests of the people involved and the importance of it with data availability. According to the article of the "Journal of Consumer Affairs, "is quoted that" young people leave school without earning a basic skill to manage the affairs of their personal finances, placing them at high risk not being able to plan responsible way their financial future. Typically, risk is understood in terms of clear patterns in which the variables are related. At first it seems that there is no "risk" as such because the word "risk" is not always used, but in fact most of the risks represented by the values of the uncertain future of the variables in these models. 1

Keywords: Management of personal finance, consumer, auditing, model of economization.

\section{The Goal of the Paper}

According to the article of the "Journal of Consumer Affairs, "is quoted that" young people leave school without earning a basic skill to manage the affairs of their personal finances, placing them at high risk not being able to plan responsible way their financial future. In order to benefit from the knowledge and competence in financial behaviors, students and consumers need to understand the problems encountered in the market. They must have the knowledge and training necessary in order to protect the best way possible for themselves from falling into financial ignorance victim.

\section{Introduction}

In studies taken as example it is found that students lack the knowledge on personal finance. On the other hand it indicates that there is insufficient tutorials and workshops for all students provided by state institutions and hinted at why students are less knowledgeable in the field of personal finance. Studies have shown that people generally have higher levels of education, have a higher level of financial knowledge, although many studies have found that the level of financial literacy is still low. This can be avoided through financial education and open seminars and university courses located in personal finances.

Financial Literacy has important implications for financial behavior. For example, people with low knowledge and financial literature are more likely to have problems with debt (Lusardi \& Turfano, 2009), and less likely to participate in the capital market (Rooij, Lusardi, \& Alessi, 2007), with little opportunity to choose mutual funds with lower fees, fewer opportunities to accumulate wealth and to manage the assets effectively and less likely to plan retirement (Lusardi \& Mitchell 2006).

Finance is an important financial component for decision making and more people require as much financial knowledge you need even more today. $84 \%$ of university students said that you needed more education on financial 
management topics, $64 \%$ would like to get information about topics of Financial management in high school (N.Shaari, N.Hasan, R. mohamed, M.Sabri "financial literacy: A study Among university students).

Risk management study began after World War II. Risk management has been long and is connected with the use of market insurance to protect individuals and companies from various losses associated with accidents.

\subsection{Roles and responsibilities in internal control}

Everyone in the organization has some responsibility for internal control 2:

$>$ Managers - are directly responsible for all activities of the organization, including design, implementation, monitoring and maintaining proper functioning and documentation of internal control system. Their responsibilities vary depending on their function in the organization and characteristics of the organization.

$>$ Internal auditors - examine and contribute to the continuing effectiveness of the internal control system through evaluations and recommendations and therefore play an important role in effective internal control. However, they have no key management responsibilities for designing, implementing, maintaining and documenting internal control.

$>$ Staff members - also contribute to the internal control. Internal control is a detailed or implied duties of each. All staff members play a role in the results of the control and should be responsible for reporting problems of activities, non-compliance with the code of conduct or policy violations.

$>$ Outside parties - also play an important role in the internal control process. They can contribute to achieving the objectives of the organization or can provide useful information to influence internal control. However, they are not responsible for the design, implementation, proper functioning, maintenance and documentation of the internal control system of the organization.

$>$ Supreme Audit Institutions (SAI) - encourage and support the establishment of effective internal control in government. The assessment of internal control is essential for SAI audits of implementation of laws and regulations, financial audits and performance. They communicate their findings and recommendations of interest.

$>$ External auditors - audit certain government organizations in some countries. They and their professional bodies should provide advice and recommendations regarding internal control.

$>$ Lawmakers and regulators - establish rules and guidelines relating to internal control. They should contribute to a common understanding of internal control.

$>$ Other parties - interact with the organization (beneficiaries, suppliers, etc.) And provide information about the achievement of its objectives

Other forms of risk management, insurance alternatives for market surfaced during the 1950s when the insurance market is perceived as too costly and not full protection against pure risk. The use of derivatives as risk management instruments were established during the 1970s and expanded rapidly during the 1980s, as companies intensify in managing their financial risk. International regulation of risk began in 1980, with financial firms held internal models of risk management and calculation formulas membership hand protection against unforeseen risks.

\section{Literature Review And Hypotheses}

At the same time, the governance of the frame of a large risk management essential for integrated risk management, introducing and membership officer positions created for managing risk. However, these regulations, the rules of governance and risk management methods failed to prevent the financial crisis that began in 20073. Statement of Cash Flow (Cash Flow) reports inflows and outflows are classified as cash from operating activities, investing and financing.

Fluxes from investment activities are those fluxes resulting from the purchase or sale of property, plant, and equipment of a subsidiary or business segment and the purchase or sale of investments in other firms. Investment Activities include activities related to the purchase and sale of property.

- Fluxes from financing activities are the fluxes resulting from the issuance or repayment of debt or issuing

2 http://www.issai.org/media/13329/intosai_gov_9100_e.pdf, date 26.02.2015, faqe 43-44

${ }^{3}$ http://neumann.hec.ca/gestiondesrisques/13-02.pdf, Risk management: History, definition and critique 6 September 2013 Georges

Dionne, vizituar me datën 20.02.2015 
equity withdrawal and dividends paid to shareholders. Related financing activities or repayment of capital inflows. Two main sources of such funds are the owners and creditors

- Fluxes from operating activities include cash effects of all transactions not classified as investing or financing activities. Operational activities are part of the daily transactions of the business operation.

- Overview of cash flows as a tool of analysis of financial statements, cash flows used by analysts to review the liquidity situation and better perception of factors affecting cash surplus of the entity over a specified period of Practice. Statement of Cash Flow (Cash Flow) is an important analytical tool for creditors, investors and any other user data that helps in determining statements of these indicators:

- The ability to generate cash fluxes in the future

- Ability to cope in times of monetary obligations

- External financing needs in the future.

- Success in the management of financing activities

- Efficiency Strategy implementation and investment financing.

\section{Research Goal}

Accounting principle for the construction of the statement of cash flow is accounting principle of base money, and not the principle of rights and liabilities assumed (accrual accounting), used for the construction of other financial statements. This overview, measures the inflows and outflows, according to the moments of time when they are realized regardless of when revenue and expenses recognized in the accounts.

Table of inflows and outflows

\begin{tabular}{|l|l|}
\hline Inflows & Inflows \\
\hline$(-)$ Assets Accounts & $(-)$ Assets Accounts \\
\hline$(+)$ Liabilities Accounts & $(+)$ Liabilities Accounts \\
\hline$(+)$ Capital accounts & $(+)$ Capital accounts \\
\hline
\end{tabular}

There are two methods to calculate the net effect of operating cash flow, the direct method or direct, and indirect or indirect methods.

Direct Method, which lists all the specific cash flows, which are associated with profit after tax such as the purchases of materials, pay wages of employees, receipts from sales of products and services, payments for rents and energy costs etc. (recommended by the standard IAS 7).

Indirect method, according to which cash flow is calculated starting from the profit after tax in the Income Statement. The indirect method calculates cash flow from operations in four steps:

Step 1) Starting with net profit

Step 2) Remove the profits or losses resulting increase as cash flows from investing or financing (such as gain from the sale of land)

Step 3) Add all non-cash expenses (such as depreciation of machinery and good name).

Step 4) Add accounts changes in balance sheet assets and liabilities arising as a result of operational activities

Total cash flow is equal to the sum of cash flows from operations, cash flows from investing and financing cash flows. If done correctly the total of cash flows will equal the change in status of cash at the beginning of the period with the situation at the end of the period.

Total cash flow is equal to the sum of cash flows from operations, cash flows from investing and financing cash flows. If done correctly the total of cash flows will equal the change in status of cash at the beginning of the period with the situation at the end of the period.

\subsection{Definition of the control system}

Internal control is an integral process that is affected by the entity's management and personnel and is designed to handle the risks and provide reasonable assurance that the pursuit of the mission of the entity, the following general 
objectives are being mett:

execution of activities in an orderly, ethical,

economic, efficient and effective;

fulfillment of obligations towards responsibility;

implementation of applicable laws and regulations;

preservation of resources from loss, misuse and destruction.

As part of the integrated management system or business membership organization, internal control should be understood,carried out and actively escorts from the board of directors, management and other personnel, to mitigate the risks of a business or organization to achieve its objectives through ${ }^{5}$

$>$ effective and efficient strategy and operational processes;

$>$ securing reliable information for users internal and external to obtaining timely and effective decisions;

$>$ securing acting in accordance with laws and regulations, and also with its politics as, procedures and guidelines;

$>$ the maintenance of its resources from loss, fraud, abuse, and injuries; and

$>$ the maintenance of availability, confidentiality and integrity of IT systems.

Internal Control supports management of organizations or businesses in achieving their strategic objectives through effective and efficient operations, enables storage resources by providing reliable information, and provides membership acting in accordance with laws and regulations.

\subsection{The importance of using financial reports.}

Analysts analyze the financial statements of a company to gain a deep understanding of financial decision making and operational performance of the company. The financial data are converted into reports to make them easier to analyze.

Examination of key reports provides an overview of how the company is performing compared with other years in its industry and economy as a whole. Although there are thousands of reports that can be calculated, it has a relatively small subset that an analyst should focus.

Reports used to evaluate five key performance features and conditions of a company like:

1. Internal Liquidity

2. Operational Performance

3. Risk Profile

4. External Liquidity

5. The potential growth

Reports Analysis includes methods of calculation and interpretation of financial reports to assess the financial situation and performance of the firm. It is of interest to shareholders, creditors, and managers of the firm or financial institution itself in our case.

\subsection{Liquidity ratios}

With liquidity means the ability of a company or institution to pay its short-term obligations when they will mature. Liquidity analysis is very important for creditors, suppliers, management and other interested organization's ability to meet shortterm liquidity requirements. Liquidity analysis a dose of uncertainty: forecasting future ability to meet future needs for liquidity. The forecast made according to historical records of the institution and no financial report can not serve as a proxy of future developments. Current ratio is the best measure of liquidity:

Control systems should be developed and implemented to give management the right balance between risk that business objectives are not achieved and the level of control required to ensure fulfillment of business objectives. ${ }^{6}$.

\footnotetext{
${ }^{4}$ http://www.issai.org/media/13329/intosai_gov_9100_e.pdf, shikuar me daten 26.02.2015, faqe 6

5 http://www.ifac.org/sites/default/files/publications/files/global-survey-on-risk-manag.pdf, shikuar me daten 26.02.2015, faqe 9

${ }^{6}$ file:///C:/Users/shxhema/Downloads/Doracaku\%20i\%20procedurave\%20te\%20Menaxhimit\%20Financiar\%20dhe\%20Kontrollit\%20(1).p $d f$, seen on date 25.02.2015, page 111
} 


\section{Sample and Data Collections}

According to the International Organisation for Supreme Audit Institutions of (INTOSAI): Internal control is an integral process carried out by's management and staff of an organization or business and designed to address the risks by providing reasonable assurance in achieving the mission of the organization or business, being achieved general objectives in the following?:

$>$ Regular executive operations efficient and effective, ethical and economic development;

Fulfilling accountability obligations;

Compliance with laws and regulations;

$>$ Providing resources not loss, misuse and damage.

Internal control consists of five components, which must be present and make the efficient functioning of the internal control of them are ${ }^{8}$ :

$>$ The control environment;

$>$ Risk Management;

$>$ Control activities;

D The debt ratio shows how part of the financing of the company or institution is performed through debt. This report takes into account all assets financed by debt. Mathematical interpretation of this measure is that it reaches the source cover the debt, the company's total assets.

$>$ Indirectly, this indicator tells us the owner rights over the asset. In 2009 we have a fund of $0.85 \%$ through debt, while in the following years this percentage has declined, exactly with $0.84 \%$ in 2010 and $0.82 \%$ in 2011 .

$>$ This means that the company has been growing its assets by reducing the ratio of debt financing through.

\section{Conclusions}

Usually viability reports put the size of the profit counters (taken from the statement of income and expenditure) and appointing a resource size (taken from the balance sheet) invested to achieve this profit. Otherwise termed viability metrics and profitability metrics. Profitability indicators can be compared with the average rate of return on deposits in the market. They aim to measure the performance of the company to one or more training periods making the size of the profit realized from comparable company.

\section{References}

Elbers C., Lanjouw J. O., Lanjouw P. (2003), Micro-level Estimation of Poverty and Inequality. Econometrica, 71(1), pp. 355-364.

Raghunathan T. E., Lepkowski J., Van Voewyk J., Solenberger P. (2001) A Multivariate Technique for Imputing Missing Values Using a Sequence of Regression Models, Survey Methodology, 27, pp. 85-95.

The World Bank (2003), Construction of the consumption aggregate and estimation of the poverty line, LSMS 2002 - Albania.

Aline Coudouel, Jesko S. Hentschel, and Quentin T. Wodon Chapter 1 Poverty Measurement and Analyze.

Canova, Luciano University of Sussex (August 2006), The many dimensions of poverty in Albania: income, wealth and perception

World Bank Institute (August 2005), Chapter 1. What is Poverty and Why Measure it?

World Bank Institute (2005), Chapter 2. Measuring Poverty

World Bank Institute, Chapter 8. Understanding the Determinants of Poverty

Amara Amjad Hashmi and Maqbool.H. Sial, Trends and Determinants of Rural Poverty: A Logistic Regression Analysis of Selected Districts of Punjab.

Betti G. and Neri N. (June 2010), Further Updating Poverty Mapping in Albania

\footnotetext{
${ }^{7}$ http://www.ifac.org/sites/default/files/publications/files/global-survey-on-risk-manag.pdf, seen on date 26.02.2015, page 10

8 file:///C:/Users/shxhema/Downloads/Doracaku\%20i\%20procedurave\%20te\%20Menaxhimit\%20Financiar\%20dhe\%20Kontrollit\%20(1).p $d f$, seen on date 26.02.2015, page 113
} 